\title{
Sposoby wykorzystania napisów scenicznych jako metody przekładu spektakli teatralnych w trakcie Malta Festival Poznań 2017
}

\author{
Surtitles in translation of theatrical \\ performances during Malta Festival Poznań \\ 2017 - analysis
}

\author{
Matgorzata Czubińska \\ INSTYTUT FILOLOGII ROMAŃSKIEJ, UNIWERSYTET IM. ADAMA MICKIEWICZA \\ AL. NiEPODLEGŁOŚCI 4, 61-874 POZNAŃ \\ malgorp@amu.edu.pl
}

\begin{abstract}
As a result of the internationalization of theatrical art and the development of modern technologies, surtitles are currently one of the most frequently used methods of theater translation. The diversity of solutions currently proposed by theaters around the world entails the necessity of development of the common rules of the creation of surtitles. This role is to be fulfilled by the French rulebook prepared by the by the drama institute Maison Antoine Vitez, entitled "Guide du sur-titrage au théâtre" (Bataillon, Muhleisen, Diez, 2016). The following analysis is based on examples of the use of surtitles from four performances presented during the Malta Festival 2017 in Poznań. Its purpose will be to answer the question: to what extent the surtitles used during the Polish festival of theater are in compliance with the norms suggested by authors of "Guide du sur-titrage au théâtre" (2016)?
\end{abstract}

\section{Wstęp}

W dobie rozwoju technologicznego oraz wywołanych nim dynamicznych zmian w sposobach komunikacji, przekładoznawstwo staje w obliczu konieczności scharakteryzowania wyzwań, które niosą ze sobą nowe metody translacji. W świecie, w którym ekrany pełnią rolę 
Matgorzata Czubińska: Sposoby wykorzystania napisów scenicznych jako metody przekładu spektakli teatralnych $w$ trakcie Malta Festival Poznań 2017

nieodłącznych towarzyszy człowieka już od pierwszych miesięcy jego życia, a komunikacja coraz częściej przybiera formę ikoniczną, komponent werbalny jest najczęściej zredukowany do roli jednego z wielu elementów przekazu, jak ma to miejsce w przypadku filmów, reklam, gier czy nowych form porozumiewania się za pośrednictwem portali społecznościowych $\mathrm{w}$ postaci tzw. postów, tweetów czy też memów. Multisemiotyczny charakter nowych form komunikacji pociąga za sobą pojawienie się nieznanych dotąd metod translacji, które nie mogłyby istnieć bez najnowszych zdobyczy technologii. Jedną $\mathrm{z}$ wartych uwagi form przekładu, która pojawiła się na przestrzeni ostatnich dziesięcioleci jest tłumaczenie spektakli teatralnych $\mathrm{z}$ wykorzystaniem napisów scenicznych. To stosunkowo niedrogie oraz pozornie niewymagające dużego nakładu pracy rozwiązanie niesie ze sobą jednakże liczne wyzwania wynikające ze specyfiki teatru oraz ograniczeń natury technicznej. Ostateczny kształt spektaklu z napisami zaprezentowanego obcojęzycznej publiczności staje się wypadkową wielu czynników i zależy od nakładu pracy całej grupy osób zaangażowanych $\mathrm{w}$ przygotowanie przedstawienia, co zostanie ukazane $\mathrm{w}$ poniższej analizie.

\section{Napisy sceniczne - od historii do wyzwań współczesności}

Tłumaczenie spektakli teatralnych przy pomocy napisów pojawiających się nad sceną lub na elementach scenografii symultanicznie wobec gry aktorskiej nosi angielską nazwę surtitling lub francuską surtitrage. Same napisy $\mathrm{w}$ obu językach nazywane są odpowiednio surtitles oraz surtitres, co z jednej strony odzwierciedla miejsce, w którym zazwyczaj wyświetla się je podczas spektaklu, z drugiej natomiast nawiazuje do przekładu audiowizualnego (subtitles/sous-titres subtitling/sous-titrage), z którego ten typ tłumaczenia teatralnego czerpie inspirację. W języku polskim obecnie można spotkać się $\mathrm{z}$ dwiema nazwami, a mianowicie „nadpisy” oraz „napisy”. W publikacjach naukowych poświęconych przekładowi audiowizualnemu badaczki takie jak Teresa Tomaszkiewicz (2006), Małgorzata Tryuk (2010) czy Anna Rędzioch-Korkuz (2013) posługują się neologizmem nadpisy, który ukuty został na wzór angielskiego lub francuskiego odpowiednika i stosują go głównie w kontekście przekładu opery. Drugi, pozbawiony niuansu semantycznego, neutralny termin napisy jest stosowany w środowisku teatralnym; można go spotkać na afiszach spektakli, w ich opisach oraz na stronach internetowych teatrów.

Przyjmuje się, że po raz pierwszy napisy zostały wykorzystane w celu tłumaczenia opery „Elektra” Richarda Straussa, która została wystawiona 21 stycznia 1983 roku w Toronto, w Kanadzie. Canadian Opera Company zdecydowała się na symultaniczne wyświetlanie angielskich napisów 
Matgorzata Czubińska: Sposoby wykorzystania napisów scenicznych jako metody przekładu spektakli teatralnych $w$ trakcie Malta Festival Poznań 2017

będących tłumaczeniem niemieckojęzycznego libretta nad proscenium. Głównym inicjatorem i pomysłodawcą przedsięwzięcia był Lotfi Mansouri, ówczesny dyrektor, który zainspirował się podpisami towarzyszącymi produkcjom filmowym (Rędzioch-Korkuz 2013: 47). I choć pierwsze próby zastosowania napisów operowych nie spotkały się z entuzjastycznym przyjęciem, gdyż decydującym się na ten odważny i ryzykowny krok reżyserom operowym i dyrektorom zarzucano profanację sztuki oraz zachęcanie widzów nieznających libretta do intelektualnego lenistwa, z biegiem lat nie tylko ekran z napisami nad sceną przestał szokować, ale stał się powszechnie stosowaną metodą translacji umożliwiającą recepcję tego postrzeganego jako elitarny gatunku muzyczno-dramatycznego.

Co się zaś tyczy sztuki teatralnej, napisy sceniczne upowszechniły się i na dobre wpisały w pejzaż teatralno-festiwalowy dopiero wraz z rozwojem współczesnych technologii na przełomie XX i XXI wieku. Wskutek umiędzynarodowienia sztuki teatralnej i dzięki licznym festiwalom, stanowiącym platformę wymiany artystycznej i interkulturowej, tłumaczenie $\mathrm{w}$ formie napisów scenicznych jest obecnie jedną z najczęściej wykorzystywanych metod translacji spektakli. Jak zauważają autorzy publikacji „Guide du sur-titrge au théâtre” (Bataillon, Muhleisen, Diez 2016), odnosząc się do aktualnej sytuacji we Francji, obecnie publiczność festiwali teatralnych organizowanych $\mathrm{w}$ tym kraju oczekuje, iż sztuki zagraniczne będą tłumaczone $\mathrm{w}$ ten właśnie sposób. I choć samo zapewnienie tłumaczenia $\mathrm{w}$ formie napisów scenicznych nie gwarantuje pełnej widowni, jego brak mógłby spowodować rozczarowanie widzów, którzy w ciągu ostatnich lat zdążyli już przywyknąć do tej metody przekładu i uznać ją za normę.

\section{Interdyscyplinarny charakter napisów}

Wyzwania, jakie stawia ta nowoczesna metoda translacji zarówno przed praktykami, jak i przed badaczami przekładu, wynikają z faktu, iż sytuuje się ona na styku wielu dyscyplin, a jej opis nastręcza wielu trudności. Mamy wszak do czynienia z tłumaczeniem literackim, które pojawia się $\mathrm{w}$ kontekście utworu teatralnego funkcjonującego jako tekst multisemiotyczny, czyli łączący komponenty werbalne, wizualne i akustyczne w jedną nierozerwalną całość (Snell Hornby, 2006). Dodatkowo w przypadku napisów dochodzi do zmiany medium języka i przejściem od jego formy mówionej do formy pisanej. Niemiecka badaczka napisów teatralnych, Yvonne Griesel $(2009,2011)$ zauważa także, iż jest to „hybrydowa” metoda translacji, ponieważ łączy cechy przekładu tekstów pisemnych oraz ustnych. Przekład nie powstaje wyłącznie na podstawie tekstu scenariusza, lecz na podstawie jego konkretnej realizacji w postaci gry aktorskiej, co wymaga od tłumacza pracy z nagraniem spektaklu, a także uczestnictwa w próbach. Owa hybrydowość i interdyscyplinarność nie pozostaje bez wpływu na odbiór przekładu, gdyż jak twierdzą Bruno Péran oraz Agnès Surbezy, w trakcie tłumaczonego na język obcy spektaklu 
Matgorzata Czubińska: Sposoby wykorzystania napisów scenicznych jako metody przekładu spektakli teatralnych $w$ trakcie Malta Festival Poznań 2017

pojmowany $\mathrm{w}$ tradycyjnych kategoriach widz (spectateur) staje się „widzoczytelnikiem” (spectalecteur) (Surbezy, Péran, 2010: 82). Na koniec należy zaznaczyć, iż napisy sceniczne, które stanowią dodatkowy element siatki semiotycznej spektaklu, mogą wchodzić w twórczy dialog $\mathrm{z}$ pozostałymi komponentami dzieła (wizualnymi, werbalnymi czy akustycznymi), uzupełniać je czy stanowić artystyczną wartość dodaną, co doskonale obrazuje choćby kreatywne wykorzystanie napisów scenicznych przez francuską reżyserkę Ariane Mnouchkine i spektakle wystawiane w jej reżyserii przez paryski Théâtre du Soleil.

\section{Tłumaczenie spektakli $z$ wykorzystaniem napisów - w poszukiwaniu normy}

Wobec wyżej wymienionych wyzwań należy zadać sobie pytanie o reguły, którym podlegałaby praca tłumacza, o wytyczne czy też normy stanowiące drogowskazy prowadzące go przez to niełatwe zadanie. Za punkt wyjścia do zaprezentowanych $\mathrm{w}$ dalszej części rozważań niech posłuży cytat zaczerpnięty z pracy zatytułowanej „Nadpisy operowe w Polsce - między teorią a praktyką" (2013) autorstwa Anny RędziochKorkuz, odnoszący się wprawdzie do napisów operowych, jednakże wyjątkowo trafnie opisujący sytuację, z którą mamy również do czynienia w teatrach:

„Pomimo istniejących wskazówek czy zaleceń nie można mówić o przyjętych standardach, które wykraczałyby poza mury danej instytucji. Zasady dobrej praktyki „surtitlera”, jeśli w ogóle istnieją, są opracowywane przez pracowników danej opery $\mathrm{w}$ formie dokumentów przeznaczonych do użytku własnego. Oznacza to, że w praktyce można zetknąć się z przeróżnymi sposobami postrzegania nadpisów i ich funkcji." (Rędzioch-Korkuz, 2013: 47)

Wobec różnorodności proponowanych obecnie przez teatry na całym świecie rozwiązań, niezbędne stało się wypracowanie wspólnych zasad tworzenia napisów teatralnych w postaci „kodeksu” definiującego wypracowane przez lata przez tłumaczy, reżyserów i osoby odpowiadające za obsługę techniczną praktyki. Taką rolę ma spełniać w zamierzeniu jego twórców opracowany przez francuski Instytut teatralny Maison Antoine Vitez zbiór reguł zatytułowany „Guide du sur-titrage au théâtre” (Bataillon, Muhleisen, Diez, 2016), który powstał jako owoc konferencji poświęconej napisom scenicznym. Spotkanie, w którym uczestniczyło ponad 30 osób reprezentujących różne środowiska - tłumaczy, redaktorów, reżyserów, badaczy tej formy przekładu oraz osób odpowiedzialnych za wyświetlanie napisów pochodzących m.in. z Francji Belgii, Niemiec, Włoch, Polski,

${ }^{1}$ Znamienne jest, iż dotąd nie powstała nazwa tej profesji w języku polskim. 
Matgorzata Czubińska: Sposoby wykorzystania napisów scenicznych jako metody przektadu spektakli teatralnych $w$ trakcie Malta Festival Poznań 2017

Litwy, Rosji, Chin, Iranu czy Korei, odbyło się 3 lutego 2014 roku w Paryżu i stało się okazją do wymiany poglądów oraz wypracowania wspólnych norm użycia napisów scenicznych. Autorzy poradnika kierują swój zbiór wskazówek nie tylko do tłumaczy, ale i do reżyserów, organizatorów festiwali teatralnych, inspicjentów, osób odpowiedzialnych za zagraniczne tournée teatrów, a także osób odpowiedzialnych za produkcję i stronę techniczną, czyli wszystkich tych, którzy, przytaczając słowa autorów: „nie wiedzą, a jeśli wiedzą, to niestety zapominają, jak skomplikowanym procesem jest opracowanie napisów do spektaklu" (Bataillon, Muhleisen, Diez, 2016).

Autorzy publikacji wymieniają i szczegółowo charakteryzują trzy główne etapy pracy nad napisami do spektaklu. Jest to tyle ważne, iż każdy etap niesie konkretne wyzwania i ograniczenia:

> tłumaczenie tekstu scenariusza sztuki - etap typowo literacki, thumaczenie najczęściej zlecane jest utytułowanym tłumaczom literackim, istnieje także możliwość wykorzystania i adaptacji istniejącego przekładu;

$>$ découpage (fr. cięcie) i obróbka techniczna (przygotowanie pokazu slajdów) - etap polegający na kondensacji i selekcji treści, który bynajmniej nie polega na pocięciu istniejącego thumaczenia na plansze. Na tym etapie pojawia się konieczność pracy z nagraniem spektaklu i uczestnictwa $\mathrm{w}$ jego próbach $\mathrm{w}$ celu dostosowania liczby, zawartości i tempa wyświetlania plansz do rytmu i tempa spektaklu, jego pauz i specyfiki gry aktorskiej. Polski pisarz, tłumacz i teatrolog, Jerzy Limon w następujący sposób oddaje charakter tego etapu pracy: „Przygotowanie tekstu do wyświetlania zabiera mnóstwo czasu, nie mówiąc o tym, że tłumacz musi skoordynować sekwencje dialogowe z tym, co rzeczywiście dzieje się na scenie podczas danego przedstawienia. Tego nie da się zrobić maszynowo czy komputerowo, bo każde przedstawienie ma inne tempo." (2014)

$>$ wyświetlanie napisów podczas spektaklu - etap wymagający od tzw. surtitlera nie tylko biegłości $\mathrm{w}$ zakresie obsługi programów służących do wyświetlania napisów, lecz również opanowania, refleksu i doskonałej znajomości scenariusza sztuki i gry aktorskiej, co staje się nieodzowne w przypadku improwizacji aktorskich, pominięcia fragmentów wypowiedzi postaci czy przeskakiwania przez aktora replik.

Ze względu na specyfikę każdej fazy pracy, zalecane jest, by nad każdym etapem czuwała inna osoba, wyróżniająca się odpowiednimi kwalifikacjami oraz kompetencjami.

Autorzy „Guide du sur-titrage au théâtre” (2016) nie poprzestają na ogólnej charakterystyce wyzwań związanych z każdym etapem pracy, lecz skrupulatnie opisują zarówno aspekty przekładowe, jak i typograficzne, 
Matgorzata Czubińska: Sposoby wykorzystania napisów scenicznych jako metody przektadu spektakli teatralnych $w$ trakcie Malta Festival Poznań 2017

informatyczne czy scenograficzne. Kilka przywołanych poniżej przykładów pozwoli ukazać szczegółowość podanych przez autorów wytycznych:

$>$ tekst powinien pojawiać się na czarnym tle i być koloru białego;

$>$ długość każdego napisu to maksymalnie dwie linijki tekstu po 35-40 znaków każda;

> optymalny czas projekcji każdego napisu to 3-4 sekundy;

> należy używać czcionki bezszeryfowej, która ułatwia czytanie z większej odległości, najlepiej stosować czcionkę Arial;

$>$ zalecany rozmiar czcionki to od 17 do 22 punktów;

$>\mathrm{w}$ tekście nie należy używać kursywy, pogrubień, pisowni wielkimi literami;

$>$ tekst napisu winien być wyśrodkowany;

> nie należy używać zbędnych znaków interpunkcyjnych, w szczególności wielokropka kończącego wypowiedź bohatera;

$>$ jeden napis powinien odpowiadać jednej jednostce sensu;

> napis powinien być na tyle jasny składniowo, leksykalnie i semantycznie, by widz mógł go zrozumieć w ułamku sekundy, bez konieczności wnikliwego czytania, co skutkuje oderwaniem uwagi od gry scenicznej;

$>\mathrm{w}$ momentach ciszy na scenie niezbędne jest użycie funkcji „shutter” projektora w celu wyświetlenia tzw. czarnego ekranu;

> niedopuszczalne jest pozostawienie na ekranie ostatniej repliki słownej w monetach ciszy na scenie;

> miejsce wyświetlania napisów jest dowolne - może to być element scenografii, ściana, specjalny panel na scenie, ekran LED, ciekłokrystaliczny lub diodowy;

$>$ rozmiar ekranu/panelu zależy od pojemności sali, w przypadku sali mieszczącej 400-600 miejsc, ekran powinien mieć wymiary $3,6 \mathrm{~m}$ x $0,5 \mathrm{~m}$ (co daje możliwość wyświetlenia 2 linijek tekstu po 47 znaków każda)

Poradnik zawiera ponadto wskazówki techniczne dotyczące typów i mocy projektora, formatów zapisu plików $\mathrm{z}$ napisami, a także charakterystyki istniejących na rynku specjalnych programów komputerowych, które ułatwiają pracę nad napisami scenicznymi, takich jak Maestro (używany w trakcie Festiwalu Teatralnego w Awinionie) Torticoli, czy też Glypheo. 
Małgorzata Czubińska: Sposoby wykorzystania napisów scenicznych jako metody przekładu spektakli teatralnych $w$ trakcie Malta Festival Poznań 2017

\section{Spektakle z napisami w trakcie Malta Festival $\mathbf{2 0 1 7}$}

Malta Festival to wydarzenie, które od 1991 roku na stałe wpisało się w kulturalny pejzaż Poznania i stanowi jego wizytówkę. Od 2009 roku Malta posiada status festiwalu międzynarodowego, a od 2010 każda edycja posiada swoje hasło przewodnie, tzw. idiom, który w 2017 roku brzmiał „Platforma Bałkany”. W edycji festiwalu, która miała miejsce w drugiej połowie czerwca 2017 roku sztuki teatralne (za wyjątkiem spektakli tanecznych i sztuk bez słów), były tłumaczone przy pomocy skryptów wręczanych publiczności przed przedstawieniem oraz napisów wyświetlanych bezpośrednio na scenie lub na ekranach. Warto nadmienić, iż ze względu na międzynarodowy charakter festiwalu i liczną grupę widzów zagranicznych, organizatorzy wymagali tłumaczenia sztuk na język angielski również od artystów i teatrów rodzimych, wystawiających sztuki w języku polskim. Zaproponowana poniżej analiza opiera się na sposobach wykorzystania napisów scenicznych na przykładzie czterech spektakli zaprezentowanych w ramach Malta Festival 2017 - dwóch obcojęzycznych, tłumaczonych na język polski oraz angielski („Turbofolk”, reż. Oliver Frljić, „The Republic of Slovenia”, reż. Slovensko Mladinsko Gledališče Słoweński Teatr Młodych,) oraz dwóch wystawianych w języku polskim i tłumaczonych na język angielski („Nowa Wizja: Ekskluzje, Akty, Sublimacje” reż. Krzysztof Cicheński, Teatr Automaton, „Porno”, reż. Cezi Studniak, Teatr Nowy im. Tadeusza Łomnickiego w Poznaniu).

Celem analizy będzie próba odpowiedzi na pytanie: na ile praktyki przekładu w formie napisów scenicznych wpisują się $\mathrm{w}$ opracowane $\mathrm{w}$ postaci „Guide du sur-titrage au théâtre” (2016) zalecenia? Dodatkowo zbadany zostanie wpływ różnorakich czynników, które determinują pracę twórców nad wersją przedstawienia, której towarzyszą obcojęzyczne napisy. Zaproponowana poniżej analiza dzielić się będzie na dwie części. W pierwszej zaprezentowany zostanie sposób, w jaki odbiera spektakl $\mathrm{z}$ napisami widz. W drugiej części zostaną zaprezentowane sposoby i etapy pracy nad spektaklem $\mathrm{z}$ napisami i ograniczenia wynikające $\mathrm{z}$ interdyscyplinarnego charakteru napisów jako metody przekładu, czyli kulisy pracy tłumacza, operatora napisów i reżysera. Obie części analizy pozwolą $\mathrm{w}$ podsumowaniu udzielić odpowiedzi na pytanie, kim są tłumacze spektakli i z jakimi wyzwaniami muszą się mierzyć.

\subsection{Napisy z punktu widzenia publiczności}

Pierwszym z analizowanych spektakli jest „Turbofolk” w reżyserii Olivera Frljića - sztuka grana $\mathrm{w}$ języku chorwackim i bazująca na fenomenie stylu muzycznego powstałego w krajach byłej Jugosławii. ${ }^{2}$

${ }^{2}$ http://malta-festival.pl/pl/program/turbofolk-olivier-frljic [dostęp: styczeń 2018] 
Matgorzata Czubińska: Sposoby wykorzystania napisów scenicznych jako metody przekładu spektakli teatralnych $w$ trakcie Malta Festival Poznań 2017

Tytułowy turbofolk to mieszanka muzyki ludowej z dance i techno, która zyskała na popularności $\mathrm{w}$ latach $90 . \mathrm{XX}$ wieku, podczas wojny na Bałkanach, stając się nośnikiem idei nacjonalistycznych. 3 Specyfiką spektaklu jest fakt, iż pojawia się w nim zaledwie kilka partii dialogowych czy też monologowych, natomiast przez większość czasu aktorzy oddają się przesyconej symboliką grze scenicznej w rytm turbofolkowych piosenek, których tłumaczenie wyświetlane jest publiczności w postaci napisów. $\mathrm{Na}$ potrzeby inscenizacji z napisami spektaklu „Turbofolk” w ramach Malta Festival 2017, zastosowany został duży czarny panel znajdujący się w głębi sceny. Ze względu na efekt tzw. „odwróconej sceny” (aktorzy grają w miejscu przeznaczonym dla publiczności, natomiast publiczność staje się teatralną sceną), czarny panel, na którym wyświetlane były przy pomocy rzutnika napisy, znajdował się daleko $\mathrm{w}$ głębi sceny, dlatego napisy musiały być odpowiednio większe. Specyfika sali i aranżacja scenografii sprawily, że niestety napisy nie były widoczne w sektorach znajdujących skrajnie po lewej i po prawej stronie, co mogło mieć jednoznacznie negatywny wpływ na odbiór spektaklu przez osoby tam siedzące. Wartym podkreślenia i uwagi zabiegiem jest to, że na ekranie w głębi sceny pojawiały się aż cztery linijki tekstu, zamiast zalecanych przez autorów "Guide..” (2016) dwóch wersów. Powodem takiej decyzji organizatorów był fakt, iż spektakl tłumaczony był jednocześnie na język angielski i polski. Z uwagi na międzynarodowy charakter festiwalu, zapewniona została możliwość uczestnictwa w nim zarówno publiczności polskiej, jak i zagranicznej. Angielskie napisy pojawiały się $\mathrm{w}$ dwóch pierwszych linijkach, napisy $\mathrm{w}$ języku polskim znajdowały się poniżej, w dwóch kolejnych wersach. Długość napisów odpowiadała ww. wytycznym, tempo wyświetlania napisów było zgodne zarówno z rytmem spektaklu, jak i możliwościami percepcyjnymi publiczności.

Drugim z analizowanych obcojęzycznych spektakli jest „The Republic of Slovenia" w reżyserii Slovensko Mladinsko Gledališče "Słoweńskiego Teatru Młodych) - sztuka grana w języku słoweńskim4. Spektakl odkrywa przed widzami ciemne karty historii Słowenii - opowiada o zaangażowaniu nowo powstałego i pozornie neutralnego państwa $\mathrm{w}$ nielegalny handel bronią w czasie wojny na Bałkanach, o łamaniu embarga, o korupcji i zakłamaniu lokalnych polityków. Specyfiką spektaklu jest podział na trzy akty. W pierwszym mamy do czynienia $\mathrm{z}$ autentyczną i improwizowaną opowieścią osoby, która sama nieświadomie uczestniczyła $\mathrm{w}$ tym procederze, drugi jest skrupulatnym odegraniem zapisu stenogramów z posiedzenia polityków, trzeci akt to spektakularnie zainscenizowana rekonstrukcja (na scenę wjeżdżają $\mathrm{z}$ piskiem opon samochody) trzech wersji aresztowania oficera wywiadu, który prowadził nieoficjalne śledztwo w sprawie handlu bronią odbywającego się na polecenie ministra obrony

3 http://www.e-teatr.pl/pl/artykuly/244745.html [dostęp: styczeń 2018]

4http://malta-festival.pl/pl/program/the-republic-of-slovenia-slovensko-mladinsko-gledalisce [dostęp: styczeń 2018] 
Matgorzata Czubińska: Sposoby wykorzystania napisów scenicznych jako metody przektadu spektakli teatralnych $w$ trakcie Malta Festival Poznań 2017

pomimo przyjęcia przez władze decyzji o zakończeniu tego procederu. Spektakl „The Republic of Slovenia” został zaprezentowany również z polskimi i angielskimi napisami $\mathrm{w}$ formie 4 linijek tekstu (tym razem polskie napisy znajdowały się na górze, angielskie na dole). Spektakl stanowi ciekawy przykład dostosowania napisów scenicznych do wymogów scenografii, gdyż w pierwszym akcie napisy były wyświetlane bezpośrednio na białej kotarze będącej jej częścią, natomiast w drugim i trzecim pojawił się, podobnie jak we wcześniejszym spektaklu, czarny panel, na którym wyświetlane były nie tylko fragmenty tłumaczenia, lecz również informacje dotyczące czasu i miejsca akcji. Niestety w pierwszym akcie spektaklu pojawił się poważny problem z synchronizacją napisów. Kolejne sekwencje pojawiały się $\mathrm{z}$ opóźnieniem, a niektóre $\mathrm{z}$ replik zupełnie nie były tłumaczone, co spowodowało niepokój i konsternację niektórych widzów, którzy zaczęli nerwowo rozglądać się po sali. Brak synchronizacji napisów ze spektaklem to sytuacja wysoce niekomfortowa dla publiczności, która nie jest $\mathrm{w}$ stanie śledzić akcji $\mathrm{w}$ języku oryginalnym $\mathrm{i}$ w rezultacie traci poczucie bycia częścią wydarzenia teatralnego i zanurzenia w akcję sztuki. Przyczyny braku synchronizacji zostaną wyjaśnione w dalszej części analizy.

Pierwszym z analizowanych polskojęzycznych spektakli jest „Nowa Wizja: Ekskluzje, Akty, Sublimacje" w reżyserii Krzysztofa Cicheńskiego i w wykonaniu offowego poznańskiego Teatru Automaton 5 tworzonego przez grupę młodych, niezależnych artystów. Autor spektaklu wprowadza nas w arkana terapii poprzez sztukę. W laboratoryjnych warunkach tzw. Ekskluzywnego Centrum Cierpienia Emocjonalnego (ECCE) oraz Hodowli Organicznych Manifestów Osobowości (HOMO) pensjonariusze przeprowadzają różne akty performatywne i próbują uleczyć swoją duszę przez twórczość artystyczną, przez taniec, śpiew, muzykę czy poezję. Specyfiką spektaklu jest jego nowatorski i prowokacyjny charakter. Reżyser chętnie wykorzystuje projekcje multimedialne i muzykę, sam gra na gitarze, natomiast dialogi postaci $\mathrm{w}$ dużej mierze opierają się na improwizacji. Spektakl zawiera również dużą liczbę aluzji i odniesień intertekstualnych, przez co stanowi intelektualną przygodę dla widza. Spektakl „Nowa Wizja: Ekskluzje, Akty, Sublimacje” był odgrywany w ramach Malty z napisami w języku angielskim. Co się zaś tyczy miejsca projekcji, były one wyświetlane z rzutnika na obu ścianach bocznych sali. Ze względu na wykorzystanie projekcji multimedialnych i trzech ekranów na stałe obecnych na scenie, napisy musiały zając miejsce peryferyjne wobec akcji sztuki. Jednoczesne umieszczenie napisów na ścianach zarówno po lewej, jak i po prawej stronie sceny umożliwiało widzom siedzącym w każdym miejscu sali podążanie wzrokiem za akcją spektaklu oraz jednoczesne czytanie napisów. Głównym mankamentem napisów była ich długość oraz stopień trudności językowej. Zawiła składnia, wyszukane

5 http://malta-festival.pl/pl/program/nowa-wizja-ekskluzje-akty-sublimacje-teatr-automaton [dostęp: grudzień 2017] 
Matgorzata Czubińska: Sposoby wykorzystania napisów scenicznych jako metody przekładu spektakli teatralnych $w$ trakcie Malta Festival Poznań 2017

słownictwo i rozbudowana metaforyka napisów zdecydowanie nie pozwalały na szybkie uchwycenie ich sensu w ułamku sekundy bez szkody dla recepcji tego, co działo się na scenie.

Drugim $\mathrm{z}$ odgrywanych $\mathrm{w}$ języku polskim przedstawień jest spektakl, który gości w repertuarze Teatru Nowego im. Tadeusza Łomnickiego w Poznaniu, a mianowicie „Porno” (reż. Cezi Studniak)6. Monodram ten ukazuje opartą na faktach historię aktorki, która otrzymała w aktach węgierskiej bezpieki pseudonim "Porno". Głównym grzechem tzw. figurantki Porno, w której rolę wciela się Edyta Łukaszewska jest to, że grywa przedstawienia uliczne dla dzieci, przekazując im przy okazji jedzenie. Specyfika spektaklu polega na podziale sceny na sferę prywatną $\mathrm{i}$ publiczną. Gdy aktorka pozostaje w tej pierwszej i gra wrażliwą uliczną artystkę, jest zamknięta w klatce na środku sceny, gdy zaś wciela się $w$ inwigilujących ją agentów bezpieki - siada przy jednym z dwóch stołów ustawionych na bokach sceny głównej. Jeśli chodzi o angielskie napisy towarzyszące inscenizacji, ze względu na fakt, iż mamy tu do czynienia z teatrem repertuarowym, wykorzystana została infrastruktura odpowiednio wyposażonej do tego celu sali teatralnej. W spektaklu „Porno” zamiast specjalnego panelu do projekcji napisów, pojawil się ekran na stałe przymocowany do jednej ze ścian, przez co napisy miały charakter peryferyjny wobec spektaklu. Ze względu na umieszczenie ekranu po lewej stronie sali, niemożliwe było jednoczesne śledzenie napisów i akcji, w szczególności przez widzów zajmujących miejsca z lewej strony sceny, którzy zmuszeni byli zerkać na ekran przez lewe ramię. Dodatkowo napisy były stosunkowo długie, zawierały kilka linijek tekstu, a ich lektura była szczególnie trudna $\mathrm{w}$ momentach, w których na scenie przytaczane były naszpikowane dyskursem prawniczym fragmenty wpisów z akt bezpieki. Wszystkie powyższe czynniki dość skutecznie zaburzały recepcję przedstawienia widzom, którzy nie rozumieli języka polskiego i zdani byli wyłącznie na napisy.

\subsection{Za kulisami, czyli przekład jako dylemat}

Widz, który zasiada na widowni spektaklu z napisami oczekuje przede wszystkim, iż będą one dobrze widoczne i czytelne pod względem wizualnym, odpowiednio zsynchronizowane $\mathrm{z}$ grą aktorów, a także przystępne pod względem językowym. Nie zdaje sobie natomiast sprawy z szeregu trudności, z jakimi muszą się mierzyć w swojej pracy twórcy napisów czy też tłumacze, reżyserzy i osoby odpowiedzialne za stronę techniczna przedstawienia. Jako że uczestnictwo w spektaklu daje możliwość jedynie częściowej i niepełnej oceny końcowego efektu, niezbędne staje się zglębienie zakulisowych motywów konkretnych decyzji, które wpływają na ostateczną formę przekładu.

6 http://malta-festival.pl/pl/program/porno-teatr-nowy-im-tadeusza-lomnickiego grudzień 2017]

[dostęp: 
Małgorzata Czubińska: Sposoby wykorzystania napisów scenicznych jako metody przekładu spektakli teatralnych $w$ trakcie Malta Festival Poznań 2017

Na potrzeby niniejszej analizy osoby odpowiedzialne ze tworzenie, a następnie wyświetlanie napisów podczas wyżej opisanych spektakli, zostały poproszone o odpowiedź na kilkanaście pytań związanych $\mathrm{z}$ procesem przygotowywania napisów scenicznych do konkretnej inscenizacji. Zestawienie ich wyjaśnień i przemyśleń z wrażeniami widza spektaklu umożliwia jak najpełniejszy opis wyzwań, z jakimi wiąże się opracowanie napisów do konkretnej inscenizacji.

I tak w spektaklu „Turbofolk”7 za powstanie i wyświetlanie napisów wzięli całkowitą odpowiedzialność organizatorzy Malta Festival. Tłumaczenie scenariusza w postaci dialogów, monologów i piosenek oraz pocięcie tekstu na plansze zostało wykonane przez znaną i utytułowaną thumaczkę literacką, Dorotę Jovankę Ćirlić (Dorotę Mentzel), tłumaczkę literatury pięknej z jęz. serbskiego, chorwackiego i bośniackiego. Powierzenie przekładu profesjonalnemu tłumaczowi literatury stanowi tu swoistą gwarancję zachowania walorów artystycznych oryginału. Za wyświetlanie napisów podczas przedstawienia była natomiast odpowiedzialna Marta Giergielewicz - osoba z bogatym doświadczeniem jako inspicjent i sufler na festiwalach krajowych i zagranicznych, posiadająca doskonałą znajomość pracy nad spektaklem „od kuchni”. Napisy były przygotowane i wyświetlane za pomocą powszechnego programu do tworzenia $\mathrm{i}$ edytowania prezentacji multimedialnych Microsoft PowerPoint. Swoistym wyzwaniem dla tlumaczki i organizatorów był fakt, iż reżyser dopisał do spektaklu scenę, w której nawiązuje do kontrowersji związanych $\mathrm{z}$ cofnięciem dofinansowania festiwalu przez wiceministra Piotra Glińskiego i spowodowanej tym faktem swojej odmowy przyjazdu do Poznania. ${ }^{8}$ Przykład ten doskonale obrazuje, iż spektakl teatralny jest dziełem charakteryzującym się niezwykłą dynamiką i nieprzewidywalnością, a jego przekład w formie napisów nigdy nie osiągnie ostatecznej, skończonej wersji, jak w przypadku tłumaczenia literatury czy nawet filmów, lecz będzie ewoluował podobnie jak spektakl, któremu towarzyszy.

W przypadku kolejnego zagranicznego spektaklu - „The Republic of Slovenia" - początkowo na zlecenie organizatorów festiwalu teatralnego zostało wykonane w Polsce profesjonalne tłumaczenie literackie, natomiast cięcia i synchronizacji z napisami angielskimi dokonała Tina Malič - osoba

\footnotetext{
7 Informacje na podstawie wymiany mailowej z organizatorami Malta Festival 2017 z lipca 2017 roku oraz stycznia 2018 roku.

${ }^{8}$ Malta Festival 2017 odbył się w atmosferze skandalu związanego z cofnięciem finansowania wydarzenia przez Wicepremiera i Ministra Kultury, Piotr Glińskiego. Choć zobowiązał się on wypłacić organizatorom subwencję w podpisanej rok wcześniej umowie, wycofał się ze zobowiązania krótko przed rozpoczęciem festiwalu. Powodem odmowy był fakt, iż jeden z kuratorów Malty Oliver Frljić wystawił w 2017 roku kontrowersyjny spektakl "Klątwa", w którym, według środowisk prawicowych, dopuścił się m.in. znieważenia wizerunku Jana Pawła II. Cofnięcie dotacji z jednej strony zaowocowało crowdfoundingową akcją "Zostań ministrem kultury", w ramach której każdy chcący wesprzeć Festiwal mógł przekazać na jego organizację dowolną sumę pieniędzy, z drugiej zaś decyzją Frljicia o zbojkotowaniu festiwalu. Reżyserowany przez niego spektakl „Turbofolk” został mimo wszystko wystawiony, zawierał jednak scenę bezpośrednio odnoszącą się do zaistniałej sytuacji i decyzji reżysera.
} 
Matgorzata Czubińska: Sposoby wykorzystania napisów scenicznych jako metody przekładu spektakli teatralnych $w$ trakcie Malta Festival Poznań 2017

z Mladinsko Gledališče, która odpowiada za tłumaczenie na język angielski oraz wyświetlanie napisów podczas zagranicznych tournée teatru. $9 \mathrm{~W}$ tym przypadku również został wykorzystany będący $\mathrm{w}$ powszechnym użyciu program Microsoft PowerPoint. Na tym etapie z Tiną Malič współpracowała konsultantka znająca język polski. Jednakże przed samą premierą miała miejsce interwencja reżysera, który poprosił o zredukowanie długości polskich napisów, co zostało wykonane niemal w ostatniej chwili i pod ogromną presją czasu. Ta nieoczekiwana ingerencja reżysera nie miała jednakże wpływu na ogólną jakość napisów, ich poprawność językową czy semantyczną. Dzięki relacji osoby odpowiedzialnej za przygotowanie a następnie wyświetlanie napisów do słoweńskiego spektaklu możemy dowiedzieć się także, dlaczego w pierwszym akcie napisy pojawiały się niesynchronicznie. Otóż Brane Praznik, autentyczny uczestnik zdarzeń, o których opowiada spektakl, przedstawia tam swoją autentyczną historię. Opowiada ją jednakże w sposób improwizowany i bazując na wspomnieniach, dlatego pomimo najlepszej możliwie jakości tłumaczenia i znajomości scenariusza, osoba wyświetlająca napisy nie jest w stanie wiernie podążać za jego słowami. Jak wskazuje Tina Malič, dzięki swojemu wielokrotnemu uczestnictwu w spektaklu, operator napisów może przewidzieć pewne fragmenty improwizowanej wypowiedzi, jednakże brak synchronizacji napisów z grą aktorską jest tu nie do uniknięcia, bez względu na stopień zaawansowania narzędzi technologicznych.

Z podobnym problemem mamy do czynienia w przypadku spektaklu „Nowa Wizja: Ekskluzje, Akty, Sublimacje” w reżyserii Krzysztofa Cicheńskiego. ${ }^{10}$ Jako że sztuka ta $\mathrm{w}$ dużej mierze opiera się na improwizacji aktorskiej, głównym wyzwaniem osoby odpowiedzialnej za napisy było znalezienie akceptowalnego kompromisu, który z jednej strony umożliwi publiczności zagranicznej recepcję sztuki, z drugiej zaś nie wymusi na aktorach rezygnacji z improwizowanego charakteru ich gry. W tym przypadku po raz kolejny wyjaśnienia osoby odpowiedzialnej za przygotowanie napisów rzucają nowe światło na wcześniej wymienione mankamenty techniczne przekładu. Krzysztof Cicheński przyznał, że kilkunastolinijkowa długość napisów wymuszona była niejako spontanicznością gry aktorskiej. Podążanie za improwizowanymi dialogami i monologami zdanie po zdaniu poprzez dwuwersowe napisy byłoby utrudnione i mogłoby przynieść efekt odwrotny do zamierzonego, czyli zrodzić frustrację i irytację widza. Pomimo przywołanych wcześniej zaleceń dotyczących kondensacji napisów do długości maksymalnie dwóch linijek tekstu, zaproponowany przez Teatr Automaton kompromis,

9 Informacje na podstawie wymiany mailowej z Tiną Malič, tłumaczem oraz operatorem napisów Slovensko Mladinsko Gledališče w dniach 18-25 lipca 2017 r. oraz na podstawie ankiety dotyczącej sposobu pracy nad napisami do spektaklu „The Republic of Slovenia”.

${ }^{10}$ Informacje na podstawie wymiany mailowej z dnia 17 lipca 2017 roku z Krzysztofem Cicheńskim, reżyserem teatralnym oraz na podstawie ankiety dotyczącej sposobu pracy nad napisami do spektaklu „Nowa Wizja”. 
Matgorzata Czubińska: Sposoby wykorzystania napisów scenicznych jako metody przektadu spektakli teatralnych $w$ trakcie Malta Festival Poznań 2017

pomimo że odbiega od przywołanej wyżej „normy”, wydaje się być słusznym rozwiązaniem. Przy okazji analizy zakulisowych aspektów pracy nad spektaklem „Nowa Wizja”, warto zauważyć, iż tłumaczenia scenariusza oraz cięcia na poszczególne plansze podjął się sam reżyser. Samodzielne przygotowanie napisów było z jednej strony rozwiązaniem mającym swe powody ekonomiczne, z drugiej zaś strony miało swoje uzasadnienie artystyczne, gdyż to reżyser najlepiej zna swoją sztukę i jest osobiście odpowiedzialny za możliwie najpełniejsze oddanie sensu wypowiedzi postaci na język obcy. Napisy uprzednio przygotowane przez reżysera wyświetlała $\mathrm{w}$ trakcie spektaklu przy pomocy programu Microsoft PowerPoint osoba z obsługi technicznej teatru.

\section{Podsumowanie}

Na podstawie poddanego analizie materiału możemy zaobserwować, iż uzus zdefiniowany jako sposób opracowania i wykorzystania napisów w konkretnym spektaklu nie zawsze podąża za zdefiniowaną wcześniej normą $\mathrm{w}$ postaci wytycznych zawartych $\mathrm{w}$ wydanym i udostępnionym przez paryski Maison Antoine Vitez "Guide du sur-titrage au théâtre” (2016). Ta mniej lub bardziej zauważalna rozbieżność wynika poniekąd z dużej liczby zmiennych, którą muszą wziąć pod uwagę w swej pracy tłumacze, reżyserzy, scenografowie czy operatorzy napisów. Na efekt końcowy przedstawienia z napisami mają wpływ zarówno uwarunkowania natury artystycznej (wizja reżysera, specyfika spektaklu), instytucjonalnej (pomoc organizatora festiwalu lub jej brak), technicznej (wielkość sali, rozmieszczenie publiczności) ekonomicznej (niewystarczające środki finansowe) czy czysto pragmatycznej (brak czasu lub posiadającej odpowiednie kompetencje osoby). Teatr jest sztuką charakteryzującą się wielowymiarowością i dynamiką, zatem ciężko ująć zarówno ją samą, jak i towarzyszący jej przekład $\mathrm{w}$ sztywne ramy norm. Ujednolicenie wytycznych i nagięcie się twórców teatralnych do pewnego paradygmatu jest czynnikiem zdecydowanie ułatwiającym proces internacjonalizacji, co doskonale widać $\mathrm{w}$ zaprezentowanym korpusie - zagraniczne teatry na ogół podążają za pewnym modus operandi, a to zdecydowanie ułatwia recepcję widzom. Jeśli zaś chodzi o praktyki teatrów polskich, w świetle zaprezentowanych przykładów widać, iż wpisują się one raczej $\mathrm{w}$ przytoczoną wcześniej wypowiedź dotyczącą opery - każdy teatr stosuje własne praktyki i określa własne normy, które nie zawsze idą $\mathrm{w}$ parze z oczekiwaniami i potrzebami publiczności, co skutkuje np. peryferyjnością napisów. Inicjatywy warte uwagi pojawiają się na marginesie zinstytucjonalizowanej działalności teatralnej - $\mathrm{w}$ teatrach offowych, takich jak Teatr Automaton, których twórcy próbują znaleźć złoty środek pomiędzy wolnością artystyczną i improwizacją aktorską a sztywnymi ramami, jakie narzucają napisy sceniczne jako metoda przekładu. 
Małgorzata Czubińska: Sposoby wykorzystania napisów scenicznych jako metody przekładu spektakli teatralnych $w$ trakcie Malta Festival Poznań 2017

W świetle zaprezentowanych powyżej i poddanych analizie zarówno z punktu widzenia publiczności, jak i twórcy teatralnego przykładów rodzi się refleksja, iż opracowanie napisów to ciągłe godzenie sprzeczności i próba znalezienia kompromisu, która wpisuje się w dialektykę przekładu wyrażoną w tytule niniejszego tomu. 
Matgorzata Czubińska: Sposoby wykorzystania napisów scenicznych jako metody przektadu spektakli teatralnych $w$ trakcie Malta Festival Poznań 2017

\section{Bibliografia}

Bataillon, M., Muhleisen, L., Diez, Y-P. (2016). Guide du sur-titrage au théâtre, Maison Antoine Vitez, Paris.

https://www.maisonantoinevitez.com/telechargements/guide-pdf.pdf.

Czubińska, M. (2016). Na(d)pisy teatralne - translacja pomiędzy sztuką a techniką, Między Oryginatem a Przekładem. „Teoria thumaczenia czy teorie ttumaczeń? cz.1”. R. XXII, 2016, nr 1 (31), pp. 153-166.

Dewolf, L. (2003). La place du surtitrage comme mode de traduction et vecteur d'échange culturel pour les arts de la scène, Recherches Théâtrales $d u$ Canada, vol. 24, no 1, pp.92-108.

Griesel, Y. (2009). Surtitling: „Surtitles an other hybrid on a hybrid stage". Trans, $\mathrm{n}^{\circ} 13$, pp. 119-127.

Griesel, Y. (2011). Le surtitrage sur scène: un transfert linguistique hybride, pragmatique et artistique en même temps, w: A. Serban, J-M. Lavaur (eds.) Traduction et médias audiovisuels. Lille: Presses Universitaires du Septentrion, pp.171-182.

Limon, J., Małecka A., Sowiński M. (2014). Teatr to nie literatura, Tygodnik powszechny. Numer TP 51-52/2014. Dodatek: Odnalezione $w$ thumaczeniu. https://www.tygodnikpowszechny.pl/teatr-to-nie-literatura-25202.

Péran, B. (2010). Éléments d'analyse de la stratégie de traduction mise en œuvre dans le surtitrage, Traduire, $\mathrm{n}^{\mathrm{o}}$ 223, pp. 66-77. http://traduire.revues.org/288.

Péran, B. (2011). Le surtitreur et son surtitrage: une activité qui reste à définir, w: A. Serban, J-M. Lavaur (eds.) Traduction et médias audiovisuels. Lille: Presses Universitaires du Septentrion, pp. 157-169.

Péran, B., Surbezy, A. (2010). Surtitrage et Langue des Signes : l'expérience d'une complicité?, Traduire, $\mathrm{n}^{\circ}$ 223, pp. $77-88$. http://traduire.revues.org/295.

Tomaszkiewicz, T. (2006). Przekład audiowizualny. Warszawa: Wydawnictwo Naukowe PWN.

Tryuk, M. (2010). Co to jest tłumaczenie audiowizualne?, Przekładaniec, nr 20, pp. 26-39.

Snell-Hornby, M. (2006). The Turns of Translation Studies: New Paradigms Or Shifting Viewpoints?. Amsterdam/Philadelphia: John Benjamins Publishing Company.

Rędzioch-Korkuz, A. (2013). Nadpisy operowe w Polsce - między teorią a praktyką, Między Oryginałem a Przekładem. Przekład sceniczny: dramat, opera, piosenka. Nr 22, pp. 45-55.

Rędzioch-Korkuz, A. (2016). Opera surtitling as a special case of audiovisual translation : towards a semiotic and translation based framework for opera surtitling. Frankfurt nad Menem: Verlag Peter Lang. 